\title{
A SERIES OF MOTIVATED LANGUAGE LESSONS INTRO- DUCING DESCRIPTION AS A NEW FORM OF COMPOSITION
}

\author{
ANNA A. CONDON \\ Assistant Principal, Rogers School, Stamford, Connecticut
}

The language lessons on description outlined in the following paper were used with a class of grammar-grade pupils of average ability. The aim was to present this difficult form of composition in such a manner that the children would develop greater freedom and individuality of expression in their oral and written English. The basis of all good written work is laid in good oral work.

One day while members of the class were narrating their experiences to one another (in a socialized oral-composition period) one girl suggested that John's composition would be more interesting if he used description. She indicated the place. This brought forth a general discussion in which all the pupils agreed with her. The majority of the class felt the need of a new form of composition (description). This was aptly expressed by one pupil, who said, "Our experiences would be more interesting to relate if we knew how to describe."

If the teacher can so direct the experiences of his pupils that the problem arises in their own consciousness of need, then it is felt to be theirs and the situation is most favorable for thinking. ${ }^{\text {. }}$ In other words, the composition work becomes definitely motivated.

Teacher:

\section{LESSON I}

\section{METHOD OF PROCEDURE}

I. a) Are there any interesting places in this vicinity worthy of description?

${ }^{1}$ Dr. L. B. Earhart, Teaching Children to Study. New York: Houghton Mifflin Co., I909, chap. i, "The Nature of Logical Study." 
b) Can you recall any scenes which appealed to you during your vacation in the country? at the seashore? (Composition work, if it is to be vital, must be made individual.)

The class seemed interested in nearby lakes, springs, ponds, waterfalls, etc.

NoTE.-The teacher must now make a careful selection of an appropriate model. "If models are used intelligently in presenting new forms of composition there will be no curbing of individuality of expression on the part of the children."'

The following model was selected for this particular group of children:

"The sun gradually wheeled his broad disk down into the west. The wide bosom of the Tappan Zee lay motionless and glassy, excepting here and there a gentle undulation waved and prolonged the blue shadow of the distant mountain. A few amber clouds floated in the sky without a breath to move them. The horizon was of a fine golden tint, changing gradually into a pure apple green, and from that into the deep blue of mid-heaven. A slanting ray lingered on the woody crests and precipices that overhung some parts of the river, giving greater depth to the dark gray and purple of their rocky sides. A sloop was loitering in the distance, dropping slowly down with the tide, her sail hanging uselessly against the mast; and as the reflection of the sky gleamed along the still water, it seemed as if the vessel was suspended in the air."-From The Legend of Sleepy Hollow, Washington Irving.

2. Provide each child with a copy of a model, wisely selected to meet the needs of your particular class.

3. Begin the lesson by reading the model to the class.

Note.-The teacher's reading will enlist the interest and attention of the whole class in the beginning of the lesson.

4. Then have the children read it silently.

5. Ask them to tell you what they see. When they have a fairly good idea of the whole picture, begin the detail study.

6. Have them select the unusually effective expressions and unfamiliar words. These must be made known and stressed.

${ }^{1}$ The Teaching of English. By Dr. Paul Klapper. New York: D. Appleton \& Co. Chapter vi treats of the value of models in the teaching of composition. 
7. Ask them how they would express a similar thought. Make them feel the need of a careful choice of words.

8. Have them close their eyes. Read the selection to them again. Ask for the picture.

9. What is the main impression made on your minds when you read the paragraph?

Note.-Wait until the majority of the class feels the atmosphere of quietude in the picture.

In every motivated lesson a suggestion for further study comes from the children. Let them make their own assignment.

Io. Suggestion for a home-study assignment: Select the details in this picture which emphasize the impression of peace and quietude.

\section{LESSON II}

The aim now is to work out the technique of description with the class, viz., in effective description we should find: (a) the general impression; (b) the definite point of view; (c) a selection of details which will produce that impression; (d) a careful location of those details; $(e)$ a wealth of expressive words.

\section{Teacher:}

\section{METHOD OF PROCEDURE}

I. What picture do you see when you read the model?

2. What impression does Washington Irving wish to produce?

3. Where was he standing?

4. How does he produce that impression of peace?

5. Name the various details he selected. Teacher makes a list on the blackboard.

$\begin{array}{lll}\text { sun } & \text { clouds } & \text { reflection of sky on water } \\ \text { sea } & \text { horizon } & \text { slanting ray, etc. }\end{array}$

6. Of what did his task consist after he had selected those details? (To locate them effectively.)

7. Let us examine another descriptive paragraph to see if we can find these points. 
8. What are the points? (Teacher makes a list on blackboard as child gives them.)
(a) Impression
b) Point of view
9. Drill $\{$ c) Selection of details
d) Effective location of details
e) Choice words

Io. A number of paragraphs were examined by the class, in the light of these standards.

ir. What have we learned thus far about the new form of composition we are considering?

Note. - Let children make their own assignment.

I2. Suggestion for home-study assignment: Select an interesting description from your home reading and examine it for those points which we have thus far considered in description.

\section{LESSON III}

The aim in this lesson is as follows: By means of a simple woodland scene familiar to the class, work out with them the application of whatever technique has been acquired thus far.

Teacher:

\section{METHOD OF PROCEDURE}

I. "Let us think of a simple woodland scene near the school." After one is selected, ask what must be thought of first.

2. What impression shall we produce?

3. What must we think of next?

4. What is to be our point of view?

5. What is the next step?

6. What details shall we select if we wish to produce an impression of joy? (Make a list of the details given by the class.)

A path through the woods

Trees on each side of the path

Birds; flowers

Brook; moss-covered rocks; ferns

Sky 
7. What is the next step? (To locate these in reference to each other.)

NotE.-Use drawing here as a means of expression-a motivated drawing lesson.

8. Ask for a rough sketch of the scene. One pupil to work at the blackboard, others at seats. They will represent a path shaded by overarching trees. They will sketch birds on some of the branches. A little to the left they will represent a brook, bordered by moss-covered rocks. On the banks, they will picture the ferns. Patches of the blue sky will be drawn overhead.

9. How many are able to give that picture in words?

NoTE.-Underscore the locating words when you have written this paragraph on the blackboard:

"Before me stretches a path through the woods, shaded by overarching trees. Flying from branch to branch are the gay little birds. A little to the left runs a small brook, on whose banks grow thick ferns and wild flowers. Overhead is the clear sky."

Io. What would make our picture more interesting?

I I. What color do we find in the scene?

I2. What would make our picture even more interesting to the reader or to the listener?

I3. What sounds do we hear?

I4. Can you think of anything else that would lend interest to the scene? To what other sense could we appeal?

I5. What flowers grow there? What words expressing odor could we use?

Note.-Put on blackboard the words of color, sound, and fragrance when given by class: green foliage, fragrant violets, blue sky, babbling brook, chirping birds, etc.

I6. How many are now able to give me the picture in words? (Let as many as possible recite.)

Note.-Let pupils make the assignment.

I 7. Suggestions for a home assignment: Write the description of a simple woodland scene, introducing color, music, and fragrance.

NotE.-Do not sacrifice the truth for an effect. The children will feel the need of revisiting the spot, which seemed very familiar to them, until called upon to describe it. 


\section{LESSON IV}

The aim here is to have the children feel the need of a store of expressive words.

\section{Teacher:}

\section{METHOD OF PROCEDURE}

I. Have a few of the woodland scenes read to the class. Let pupils offer criticisms.

2. Return to the first model. Pick out the aptly chosen words; the words rich in meaning; the words that helped Irving produce the impression of quietude.

$\begin{array}{lll}\text { wheeled } & \text { blue } & \text { slanting } \\ \text { gradually } & \text { amber } & \text { blue } \\ \text { lay } & \text { floated } & \text { lingered } \\ \text { motionless } & \text { golden } & \text { uselessly } \\ \text { gentle } & \text { gradually } & \text { gleamed }\end{array}$

3. Why did Irving use "wheeled," "gradually," etc. ?

4. Have them suggest words which they would use. Note the contrast.

NotE.-Make class feel that hackneyed words would mar good writing.

5. Now re-read the paragraph. How does the picture compare with the one you had in Lesson I?

The children experienced pure delight in the final reading of the model.

6. Suggestion for a home assignment: Select from your literature or your outside reading, passages containing happily chosen words. Be able to tell how they helped the writer produce the beautiful picture.

\section{LESSON V}

(Arranged for a class which has a working knowledge of grammar)

In this lesson the aim is to have the class feel the need of a wise selection of words-especially verbs (for action), adjectives (for color), and adverbs (for effect).

NotE.- Here is an opportunity for a motivated grammar lesson on verbs, adverbs, and adjectives. The grammar is made vital by a practical application in the composition period. 


\section{Teacher:}

I. Return to the first model. Pick out the aptly chosen verbs in this selection. (Teacher writes them on the blackboard.)

$\begin{array}{lll}\text { wheeled } & \text { floated } & \text { gleamed } \\ \text { lay } & \text { lingered } & \text { was loitering }\end{array}$

2. Tell me why Irving used "wheeled," "lay," etc.

3. Select the words which give color to the paragraph. (Teacher writes them on the blackboard.)

$$
\text { blue amber golden, etc. }
$$

4. What part of speech is each?

5. What is an important function of adjectives in descriptive work? (Caution: Avoid too many adjectives.)

6. Pick out the words that help bring about a feeling of peace and quietude.

$$
\text { gradually motionless slowly, etc. }
$$

7. If this scene were one of life and activity, what adverbs would you use?

8. What is an important function of adverbs in descriptive composition?

9. Now re-read the paragraph. How does the picture compare with the one you had when we began this work?

The children experienced pure delight in the final reading of the model.

ro. Suggestion for a home assignment: Select from your literature or your outside reading passages containing happily chosen words. Be able to tell how they helped the writer produce the beautiful picture.

NoTE.-Since words give life and color to any description, we must strive to develop in the child the ability to find the right word to express the exact meaning. Just as a skilled painter chooses with care his delicate colors, so also the writer must choose the fitting words.

The class from now on will be interested in finding the happily chosen words in their literature selections and in their home reading. Encourage this all you can. Too often they "skim" over the very beautiful descriptions because they never felt the need of a store of expressive words. In all this work you are laying a sound basis for enriching the live vocabulary of the children. In other words, your work in this line is definitely motivated. 


\section{LESSON VI}

The aim is to emphasize the need of an enriched vocabulary and to create the desire to satisfy that need.

\section{METHOD OF PROCEDURE}

\section{Teacher:}

I. Begin the lesson by calling for the assigned work. While one child reads his selected paragraph to the class have the pupils fill in some such form as the following:

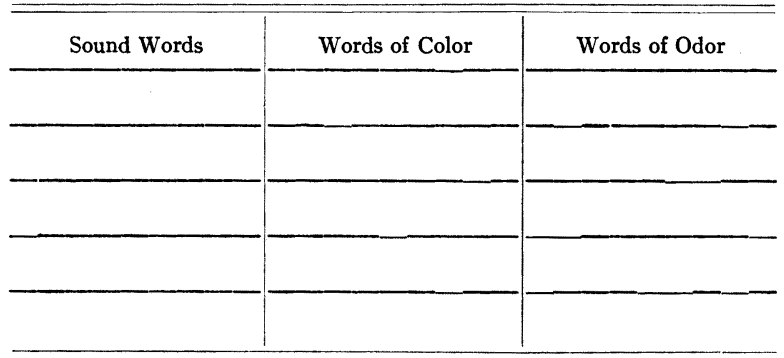

2. A definite word-study exercise like the following could be written on the blackboard:

Flow gently, sweet Afton.

The cataract leaps to the ground.

The brook rushes to the sea.

a) Pick out words expressing motion.

b) What kind of motion is expressed by each particular word?

c) Write original sentences. In each use a word of motion in connection with each of the following subjects: ocean, brook, river, clouds.

Special reference for teacher: Graded Composition Lessons. Part III, pages 26, 78, 84, 203. By Marcelia McKeon.

The following should be read to the class: Tennyson, "The Brook"; Lanier, "Song of the Chattahoochee"; van Dyke, "Little Rivers" (selection); R. Southey, "The Cataract of Lodore"; Rev. A. J. Ryan, "Song of the River." 


\section{LESSON VII}

By this time the pupils have a feeling of confidence in their own ability and a spirit of enthusiasm, both of which are very conducive to free self-expression on their part.

\section{Teacher:}

\section{METHOD OF PROCEDURE}

I. Today we shall begin our original compositions. Select your subjects and plan your compositions according to the principles we have learned thus far in this new work.

Note.-Some of the selected subjects were: "The Lake at Hallowe'en Park"; "Klinefelter's Pond"; "The Noroton River"; "The Lake at Laddins' Rock Farm."

The fruit of the foregoing work began to show itself in the spontaneous response and initiative of the class. Some suggested describing the lake in winter, for they wished to produce an impression of desolation. Others wished to paint a summer picture, for the music, color, and fragrance of that season appealed to them, while a third group preferred autumn with its rich coloring. One boy attempted a poem and "thus became our first poet."

The following plan and composition were prepared by one of the pupils:

\section{The Lake at Hallowe'en}

Impression.-Desolation. Winter scene.

Point of view.-Standing on the rustic bridge which spans the lake.

Details.-Ice-bound lake, wind, trees, lone snow-bird, steamer on the sound, sky.

Words used to bring about a scene of desolation: groan, creak, piping, shrieking, groping, booming.

The composition. - Before me lies the ice-bound lake at Hallowe'en. Held in winter's icy grip it no longer sparkles and dances as it did in summer. The biting wind sweeps up the lake causing the trees along its margin to groan and creak in dismay. A lone snow-bird who has braved the rigors of winter vainly tries to raise his piping voice above the shrieking of the wind. Now and then the weary voice of a steamer answered by the booming voice of a nearby light comes faintly to my ears. The steely gray of the sky, foretelling an approaching storm, makes the already cheerless scene one of desolation.

I This composition is reproduced as I received it. The critic informed me that the writer's errors consisted of misspelled words. These were indicated by him and corrected by the owner, before I received the paper. 


\section{LESSON VIII}

Finish the work which was begun in the preceding lesson. During these periods of written composition, it is very necessary that the teacher move about among the children in a very sympathetic spirit giving individual help and encouragement. The pupils, on the other hand, must feel perfectly free to consult books of synonyms, dictionaries, or question each other or the teacher. The movable furniture now used in most of the modern school buildings allow for the necessary freedom in such a vital subject as oral and written composition.

\section{LESSON IX}

(Correction of composition by the teacher and by the pupils)

Many teachers feel that correcting compositions is a great burden, and in many cases is time ill spent, since the same errors often reappear in the child's written work. Dr. Franklin T. Baker's suggestions on this point are very valuable: Shall the teacher correct themes? Surely. But he must know how. He must not be fussy nor pitch his standards too high. He must not forget that it is the ideas, rather than the form, that are the main thing. $\mathrm{He}$ must not forget to put the responsibility for the form on the pupil as fast as possible and make them proofread their themes.

The aim in this lesson is to develop the habit of self-criticism on the part of all the children. In order to realize this aim, however, the compositions must be short.

\section{METHOD OF PROCEDURE}

a) Criticism by teacher.-During the period of written composition the teacher is of great service to her class, for as she walks about among them she has a splendid opportunity, not only to help those who need encouragement and individual attention, but also to correct errors without curbing free expression. The child, of course, must know the cause of his error, otherwise he will never become self-critical-a habit which the teacher of composition should endeavor to help her pupils to acquire. 
Select those children who are below the standard of the grade in this work and in the conference period, make known to them their weaknesses, and aid them to acquire skill in this most useful art.

Note.-When the teacher has read the set of papers (not necessarily corrected, nor marked them) she notes the typical errors or general weaknesses of her class. She makes this work the basis of her next instruction.

References for teachers: Standards in English, J. J. Mahoney; Lawrence Course of Study in English, Sheridan; New Jersey Course of Study in English, Kendall.

b) Criticism by pupils (another period).-In the first place, make children understand that correcting or criticizing means helping, not marking.

When the class has finished writing (and before or after the teacher has read the compositions), the children exchange papers for intelligent and constructive criticism. The socialized oralcomposition period helps the pupils to acquire a habit of intelligent criticism and appreciation of the work of their fellow-pupils. They now apply these standards of judgment to the written work of their classmates. The pupils who have linguistic ability criticize the work of those who are below grade, while the latter read with inspiration and delight the papers of the former.

The papers are then returned to their owners, who proceed to follow the suggestions and correct the errors indicated by their critics. Often they confer with one another. Such a method of criticism effectively improves the written expression of children. It is infinitely superior to the weary drudgery of "red ink" correction made-by the teacher and blindly followed by the pupils.

The following are a few of the best compositions from this group of children:

\section{The Lake at Hallowe'en Park}

From the summit of the sunny hillside, on which I stand, I can see the lake at Hallowe'en, whose blue waters sparkle as they shimmer in the sunlight. Here and there I see tiny islands on which grow stately elms. The lake is bordered by thick low bushes. Farther on, to the right, are the tender trees that have been nipped by the frost into brilliant dyes of orange, purple and scarlet. Some of the little birds who have not yet departed for the warm

I This composition is reproduced as I received it. The critic informed me that an exclamation point at the end of the last sentence was suggested by him. 
regions of the South are fluttering from one limb to another. Overhead a few fleecy clouds float through the clear blue serene sky. What a delight it is to gaze at this scene in the beautiful autumn!

\section{A Winter SCENE}

All is calm and silent,

The old elms are unclad.

Hushed, are the songs of the birds,

Gone, are the flowers we had!

The water is dark and cold

Where once it danced with delight!

And the quaint rustic bridge looks gloomy and old,

As if dreading the bleak winter night.

The banks are now bare and brown,

Faded and gone are their fragrant things.

The ice-covered ponds we pass in our walk,

Reveal Jack Frost's work with the springs.

There remain the same gray rocks.

But, where is the velvet moss?

The sky is o'ercast and weary,

And the beauties of summer are lost.

Then let us be happy when summer is here,

And enjoy what the Great God has made.

Complain not my children, this time of the year,

And you will be sure of His aid!

\section{The Lake at Laddins' Rock FarM ${ }^{2}$}

Before me sparkles a beautiful lake. The golden rays of the sun, streaming through the swaying boughs of the willows and beeches, nestle peacefully on its bosom. The shining white pebbles, lying in its bottom, furnish seats for the tiny dwellers there. The shy goldfish, darting swiftly through the water, seem to fear the stately bullfrogs that leap from rock to rock. Here the birds find friends and homes. The chirping robins, the twittering sparrows among'st the others, make this spot human with their merry notes of gossip.

As I sit in one of the garden seats and gaze on this scene of beauty and listen to the united chorus of my wood friends, it almost induces me to join in their melodies. How could anyone sit here and be unhappy! The gentle summer breezes whisper that flowers are blooming near by. As with a happy

${ }^{1}$ This was the pupil's first attempt at verse making. No change whatever was made in the poem.

${ }^{2}$ Written by a former pupil, who visited this spot during the month of June. At the time we were studying "The Vision of Sir Launfal." 
and contented heart, I pluck their upturned faces, I am reminded of the "Great Seven Days' Work," wrought by the Almighty from whom comes the beauty of all things!

\section{The Lagoon at Seaside Park ${ }^{\mathrm{T}}$}

Before me, covered with sparkling snow and ice is the lagoon at Seaside Park. The moon gleams down upon the joyful skaters whose shouts ring out through the crisp air. Some distance to my left, I catch the faint outline of a hill, broken here and there by sturdy trees. To my right is a snug cottage from whose windows a ruddy light gleams. The sight makes me think of my own cozy kitchen with its blazing fire. Far in the distance I see long lines of dim street lights. The clanging of a bell tells me that a boat is pulling up to the dock.

\section{The Lake at Hallowe'en Park ${ }^{2}$}

Standing on the rustic bridge which spans the lake, I see directly in front of me, the rippling water in which little goldfishes are swimming to their hearts' content. Bordering the lake are low bushes where twittering birds are perched. Now and then the screech of a distant sea gull can be heard as he darts quickly at his prey. Here and there along the banks are moss-covered rocks which seem to have been put there to serve as resting places for the burly bull-frogs. A few small islands with their slender but stately elms dot the lake. To my right is a grassy knoll with a few benches, where visitors may rest and enjoy the refreshing breezes from the Sound.

\section{The Lake at Hallowe'en ${ }^{3}$}

I am standing on the bridge which is at one end of the lake. I see the frozen water of the lake. Here the jolly folks are skating to and fro. Often a beginner tumbles down. In the middle of this lake are two islands and on each grow elm trees. Around the edge of the lake are bushes. In the distance, as far as the eye can reach, can be seen the sandy hills of Long Island.

${ }^{x}$ Criticized by the teacher. This pupil had selected interesting details, had a store of aptly chosen words, but he was weak in sentence variety. Had a conference with him, in which we talked this matter over together. He made another attempt, focusing his attention this time on sentence betterment.

${ }^{2}$ His critic informed me that he suggested the combining of two short sentences to form the last sentence.

${ }^{3}$ The last composition submitted is typical of the poorest work done in the grade. Considerable attention is given him during the periods of written composition, for he needs sympathy and encouragement. He has ideas, but he expresses them with great difficulty. 